\title{
A curious case of Pink Saliva
}

\author{
*Shruti Sharma ${ }^{1}$, Arunima Bhardwaj ${ }^{2}$
}

Sri Lanka Journal of Child Health, 2021; 50(4): 726-727

DOI: http://doi.org/10.4038/sljch.v50i4.9899

(Key words: Foreign body, Upper gastrointestinal endoscopy, Blood tinged saliva, Infant, Oesophagus)

\section{Introduction}

Foreign body (FB) injuries present a significant health hazard, especially in infants, as they are unable to distinguish edible objects from nonedible ones due to the inherent habit of mouthing. Mostly, the parents are aware of ingestion of FBs in such cases; however there may be cases where the parents are unaware of ingested FBs.

\section{Case report}

A nine-month-old girl, born normally at term, with a birth weight of $2.7 \mathrm{~kg}$, to a non-consanguineous married couple from the rural hilly population of North India, presented with a complaint by the mother of the baby having intermittent pink coloured/blood tinged saliva for the past one week. There were no other complaints. The baby was taking her feeds adequately and passing urine and stools normally.

Her vital functions were normal and the general physical examination, as well as the systemic examination, was not remarkable. Her haemoglobin level was $9.8 \mathrm{~g} / \mathrm{dL}$ and the platelet count was $2.26 \mathrm{x}$ $105 / \mathrm{dL}$ at presentation. The coagulation parameters were normal. Her routine urine examination was normal and did not show any sediments or proteinuria. Her radiography of the upper respiratory tract, chest and abdomen was within normal limits. On abdominal ultrasound examination, spleno-portal axis, liver, spleen and pancreas were normal. Upper gastrointestinal tract endoscopy (UGIE) revealed a foreign body (grass blade) stuck in the upper oesophagus with ulcerations at the site (Figures 1 and 2).

$\overline{{ }^{1} \text { Assistant Professor, Paediatric Gastroenterology, }}$ Department of Gastroenterology, 'Junior Resident, Department of Paediatrics, Indira Gandhi Medical College, Shimla, Himachal Pradesh, India

*Correspondence: shrutichail@gmail.com

iD https://orcid.org/0000-0003-2322-9521

(Received on 29 October 2020: Accepted after revision on 18 December 2020)

The authors declare that there are no conflicts of interest.

Personal funding was used for the project.

Open Access Article published under the Creative Commons Attribution CC-BY cc) (i) License

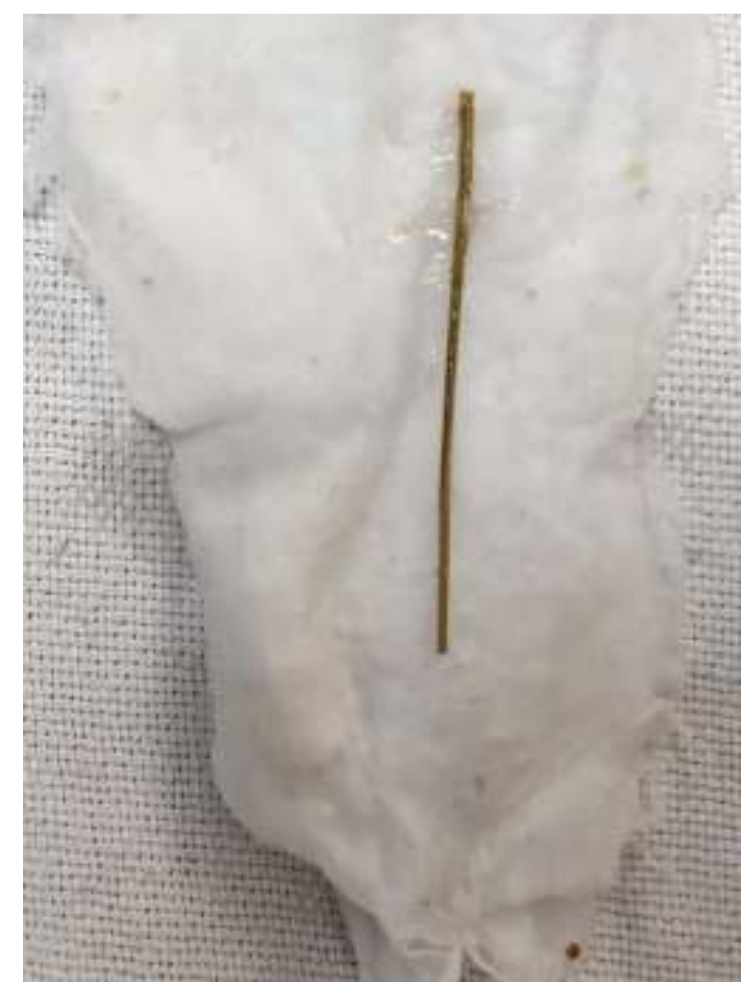

Figure 1: Grass blade extracted from upper oesophagus

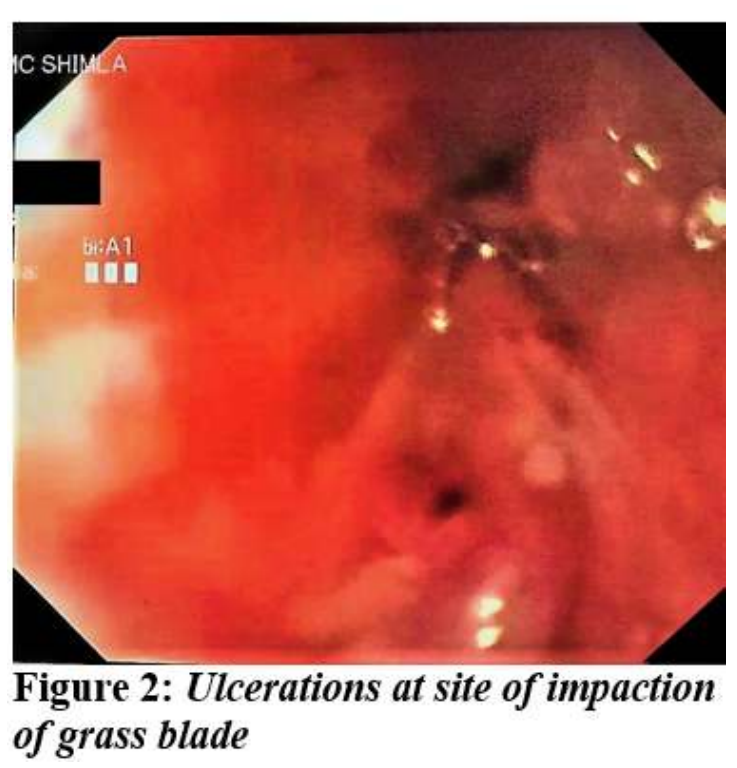

The blade of grass was removed endoscopically, and the child was asymptomatic since then. The child is on regular follow-up on an out-patient department basis for the last 2 months and has no recurrence of symptoms. 


\section{Discussion}

FB ingestion can be asymptomatic in about $30 \%$ of children $^{1,2}$, but when they present with non-specific symptoms, they can be a cause of real concern. In such circumstances, FB injury can be misinterpreted as gastrointestinal or respiratory pathology. If FB ingestion is not witnessed by the caregivers of young children, and there are no specific symptoms, there can be delay in diagnosis and treatment, thus increasing the risk of complications. Symptoms of FB ingestion depend on the anatomical location of lodgement and mostly include vomiting, dysphagia, drooling, gagging and pain ${ }^{1-3}$.

Common complications associated with FBs are gastrointestinal mucosal abrasions, ulcers, necrosis, bowel obstructions etc. The injuries can be very severe with sharp, magnetic and large $\mathrm{FBs}^{3}$, but relatively harmless objects like small grass blade can also cause trivial injuries in young children. A grass blade acting as a migrating FB has even been reported to cause repeated cervical abscesses in a young girl ${ }^{4}$. FBs in young children can present with varied symptoms and even in the absence of a definitive history of FB ingestion, an UGIE should be done in the presence of blood in saliva.

\section{References}

1. Diaconescu S, Gimiga N, Sarbu I, et al. Foreign body ingestion in children: Experience of 61 cases in a Pediatric Gastroenterology Unit from Romania. Gastroenterology Research and Practice 2016; 2016: 1-6.

https://doi.org/10.1155/2016/1982567

PMid: 26949384 PMCid: PMC4753337

2. Lakdhar-Idrissi M, Hida M. Foreign body ingestion in children: 105 case reports. Archives of Pediatrics 2011; 18(8): 85662.

https://doi.org/10.1016/j.arcped.2011.05.0 07

PMid: 21658920

3. Khorana J, Tantivit Y, Phiuphong C, Pattapong S, Siripan S. Foreign body ingestion in paediatrics: Distribution, management and complications. Medicina (Mex). 2019; 55(10).

https://doi.org/10.3390/medicina55100686 PMid: 31615117 PMCid: PMC6843858

4. Landis BN, Giger R. An unusual foreign body migrating through time and tissues. Head and Face Medicine 2006; 2: 30. https://doi.org/10.1186/1746-160X-2-30 PMid: 16965623 PMCid: PMC1570450 